\title{
Introduction: Little Words: Communication and Procedural Meaning
}

Diane Blakemore's pioneering work on the interactions between linguistic form and inferential comprehension mechanisms has had a major influence on the development of Relevance Theory (Sperber and Wilson 1986/1995; Blakemore, 1992, 2004, 2013; Carston, 2002; Wilson and Sperber, 2012; Clark, 2013). Her main research is at the interface of semantics and pragmatics, where her books Semantic Constraints on Relevance (1987) and Relevance and Meaning (2002) have made ground-breaking contributions to the study of non-truth-conditional meaning and its role in communication. She is best known for her distinction between conceptual and procedural meaning, and in particular for the notion of procedural meaning, which has been fruitfully applied not only to linguistic constructions in many languages (Brockway, 1981, Blakemore, 1988, 1989, 2000, 2007b; Blass, 1989, 1990; Matsui, 2002; Iten, 2005; Hall, 2007; Sasamoto, 2008; Unger, 2012) but also to non-verbal communication in humans and animals (Wharton, 2003, 2009). The aim of this Special Issue is to honour her work with a collection of papers by colleagues, collaborators and students. The title 'Little Words' echoes a description Diane sometimes jokingly gives of her own research; the subtitle 'Communication and procedural meaning', along with the range of papers collected here, seems to us to give a clearer idea of the originality and diversity of her work.

Diane's research on the effects of linguistic form on utterance interpretation sprang from her interest in a group of discourse connectives (e.g. but, so, also, moreover) which resist analysis in conceptual terms and are generally seen as non-truth- 
conditional. She proposed to analyse these as encoding not concepts that figure directly in the proposition expressed by an utterance but procedural "instructions" to the hearer about how the utterance is to be understood (for instance, what type of contextual assumptions should be used in processing it, and what type of conclusions should be drawn). This approach has since been fruitfully applied to a wide range of items - discourse particles, interjections, mood indicators, pronouns, expressives, etc. - which also resist analysis in purely conceptual terms and which tend to be seen as having little in common with each other in standard approaches to semantics or sociolinguistics (Clark, 1993; Wilson and Sperber, 1988, 1993; Matsui, 2000; Powell, 2010; Escandell-Vidal et al., 2011). Throughout her research, Diane has shown that these 'little words' can be fruitfully approached in terms of a unitary, cognitively grounded notion of procedural meaning. This has had particular implications for linguistic semantics, by showing how a wide range of apparently disparate phenomena might be brought within its scope.

Diane's work on the conceptual-procedural distinction, with its implications for the interface between linguistic semantics and pragmatics, has opened up new perspectives on other aspects of language use, in particular prosody and style (Blakemore, 1991, 1994, 1997, 2005, 2006, 2007a, 2009; Gutt, 1991; Noh, 2000; Papafragou, 2000; Ifantidou, 2001; Blakemore and Carston, 2005; Unger, 2006; Clark, 2009, 2012; Blakemore and Gallai, 2014; Jodlowiec, 2015; Walaszewska, 2015). Together with other relevance theorists who have worked on non-verbal communication (e.g. Wilson and Wharton 2006, Wharton 2009; Chevallier et al., 
2011), she has provided interesting analyses of a range of cases that are generally seen as 'para-linguistic' or 'stylistic', and therefore as falling outside the scope of linguistics proper. On this approach, procedural "instructions" can be carried not only by linguistic expressions but also by non-linguistic cues, so that, for instance, affective prosody may be analysed in procedural terms, and subtle variations in linguistic form (e.g. the use of parentheticals, appositives and expressives) may be seen as contributing tp inferential comprehension in ways that are hard to analyse in purely conceptual terms (Blakemore, 2008, 2010, 2011, 2015).

One of the strengths of Diane's work comes from her eye for real data. As noted above, her work has always been cognitively oriented and theory based, but she is also constantly alert to evidence from all sorts of places - literature, overheard comments, billboards, radio, road signs, films, TV, posters - belying the common criticism of work on relevance theory that it 'does not deal with real examples'. One of the best-known illustrations of this was her discussion of 'Dogs must be carried', which was taken from a sign on the London Underground. Importantly, she has been as much concerned with examples which are not acceptable in certain contexts as with those which are: as she often says, without knowing when certain expressions are not acceptable, we could not explain when they are.

Diane's work has been widely recognized in academia. In the last ten years, she has won distinguished Senior Research Fellowships from both the British Academy and the Leverhulme Trust, which have enabled her to extend her investigations to many further aspects of the relationship between pragmatics and style. Her service to the 
Linguistics community includes many years as an editor of Lingua, and as a member of the advisory board of Mind and Language. She has lectured widely in the UK and abroad, including Japan, the Netherlands, France, Switzerland, Spain, Poland and the United States.

Diane's contribution to Linguistics does not stop at her own research; she has also had a significant influence on fellow linguists. Having completed her PhD on the semantics-pragmatics interface at University College London under the supervision of Deirdre Wilson, she became a Lecturer and Senior Lecturer in Linguistics at the University of Southampton before moving north to the University of Salford, where she took up the Chair of Linguistics in 1998 and later became Director of its European Studies Research Institute. Under her leadership, the University of Salford developed a new programme in Linguistics which achieved top place in the National Student Survey in 2008. This programme added new theoretical depth to the School of Languages at Salford, which had previously been heavily oriented towards applied research, and her breadth of experience and expertise helped to build up a department with a unique combination of researchers in linguistics, language studies and translation/interpreting studies. Diane also helped to set up the North West Centre for Linguistics (NWCL), which provides research training in theoretical and applied linguistics and research methodology for graduate students.

Diane has supervised a number of young researchers working on a wide range of topics, from Japanese discourse connectives to simile, repetition and interpreting. Her commitment to teaching and supervision has been remarkable, and her students 
are extremely grateful for her dedication to mentoring new researchers and her 'finetooth comb' approach to supervision, which fostered their independence as researchers in academia. She provided them with guidance, never answers, which they still find very insightful several years later. As one of her former students says, 'She has an intuition for what is and what isn't going to be pertinent to theoretical work, and the breadth of her expertise in the field is awe-inspiring.'

The papers in this special issue give a good idea of Diane's contributions to the field. They start and end with two general reflections on the development and future prospects of the conceptual-procedural distinction: a Prologue by Deirdre Wilson ('Reassessing the conceptual-procedural distinction') and an Epilogue by Robyn Carston ('The heterogeneity of procedural meaning'). The remaining papers fall into two broad groups. The first group explores the relation between the conceptualprocedural distinction and the creation of expressive or poetic effects: Tim Wharton on the analysis of expressives ('That bloody so-and-so has retired - Expressives revisited'); Ryoko Sasamoto and Rebecca Jackson on onomatopoeia ('Onomatopoeia - Showing word or saying word? Relevance theory, lexis and the communication of impressions'); Adam Gargani on the relation between simile, metaphor and literal comparisons ('Similes as poetic comparisons'), and Kate Scott on the effects of the use of pronouns that go beyond merely securing reference ('Pronouns: Reference and beyond'). The second group explores the broader implications of the conceptual-procedural distinction: Tomoko Matsui and her colleagues report some experiments on the acquisition of procedural expressions 
('Young children's early sensitivity to indications of speaker certainty in their selective word learning'; Fabrizio Gallai analyses the omission and addition of discourse connectives by simultaneous interpreters ('Point of view in free indirect thought and in community interpreting'); Jacques Moeschler presents an alternative account of the conceptual-procedural distinction which has been widely used in analyses of French ('Where is procedural meaning located? Evidence from discourse connectives and tenses'); and Billy Clark explores the implications of the conceptualprocedural distinction for language change ('Relevance theory and language change').

\section{Acknowledgements}

In preparing this special issue we have been greatly helped in the reviewing process by Stéphane Bernard, Kaja Borthen, Liesbeth Degand, Ingrid Lossius Falkum, Thorstein Fretheim, Anne Furlong, Alison Hall, Mark Jary, Barbara Macmahon, Steve Nicolle, Didier Maillat, Olivier Mascaro, Ian Mason, Manuel Padilla Cruz, Kate Scott, Rob Stainton, Christoph Unger, Ewa Walaszewska, Tim Wharton, Akiko Yoshimura and Francisco Yus Ramos.

We are especially grateful to Johan Rooryck, executive editor of Lingua, to Anikó Lipták, editor of this Special Issue, and to our colleague Neil Smith, a former editor of Lingua, for their generous support and efficiency throughout the editing and production process, and for all they have done for Lingua over the years. Thanks also to Sara Bebbington and her colleagues for help on the technical side. 


\section{References}

Blakemore, D., 1987. Semantic Constraints on Relevance. Blackwell, Oxford.

Blakemore, D., 1988. So as a constraint on relevance. In: Kempson, R. (Ed.), Mental Representation: The Interface between Language and Reality. Cambridge University Press, Cambridge, pp. 183-95.

Blakemore, D., 1989. Denial and contrast: A relevance-theoretic analysis of 'but'. Linguistics and Philosophy 12, 15-37.

Blakemore, D., 1991. Performatives and parentheticals. Proceedings of the Aristotelian Society 91, 197-123.

Blakemore, D., 1992 Understanding Utterances. Blackwell, Oxford.

Blakemore, D., 1993. The relevance of reformulations. Language and Literature 2, 101-120.

Blakemore, D., 1994. Echo questions: A pragmatic account. Lingua 1994, 197-211.

Blakemore, D., 1996. Are apposition markers discourse markers? Journal of Linguistics 32, 325-347.

Blakemore, D., 1997. Restatement and exemplification: A relevance-theoretic reassessment of elaboration. Pragmatics and Cognition 5, 1-19.

Blakemore, D., 2000. Indicators and procedures: nevertheless and but. Journal of Linguistics 36, 463-486.

Blakemore, D., 2002. Relevance and Linguistic Meaning: The Semantics and Pragmatics of Discourse Markers. Cambridge University Press, Cambridge. 
Blakemore, D., 2004. Discourse markers. Horn, L., Ward, G., (Eds.), The Handbook of Pragmatics. Blackwell, Oxford, pp. 221-40.

Blakemore, D., 2005. 'And'-parentheticals. Journal of Pragmatics 37, 1165-1181.

Blakemore, D., Carston, D. 2005. The pragmatics of sentential coordination with 'and'. Lingua 115, 569-589.

Blakemore, D., 2006. Divisions of labour: The analysis of parentheticals. Lingua 116, 1670-1687.

Blakemore, D., 2007a. 'Or'-parenthetheticals, 'that is'-parentheticals and the pragmatics of reformulation. Journal of Linguistics 43, 311-339.

Blakemore, D., 2007b. Constraints, concepts and procedural encoding. In: BurtonRoberts, N. (Ed.), Pragmatics. Palgrave Macmillan, Basingstoke, pp. 45-66.

Blakemore, D., 2008. Apposition and affective communication. Language and Literature 17, 37-57.

Blakemore, D., 2009. Parentheticals and point of view in free indirect style. Language and Literature 18, 129-153.

Blakemore, D., 2010. Communication and the representation of thought: The use of audience-directed expressions in free indirect thought representations. Journal of Linguistics 46, 575-599.

Blakemore, D., 2011. On the descriptive ineffability of expressive meaning. Journal of Pragmatics 43, 3337-3350.

Blakemore, D., 2013. Voice and expressivity in free indirect thought representations: Imitation and representation. Mind and Language 28, 579-605. 
Blakemore, D., Gallai, F., 2014. Discourse markers in free indirect style and interpreting. Journal of Pragmatics 60, 106-120.

Blakemore, D., 2015. Slurs and expletives. A case against a general account of expressive meaning. Language Sciences 52, 22-35.

Brockway, D., 1981. Semantic constraints on relevance. In: Parret, H., Sbisa, M., Vereschueren (Eds.), Possibilities and Limitations of Pragmatics. John Benjamins, Amsterdam, pp. 57-78.

Blass, R., 1989. Grammaticalization of interpretive use: The case of re in Sissala. Lingua 79, 299-326.

Blass, R., 1990. Relevance Relations in Discourse: A Study with Special Reference to Sissala. Cambridge University Press, Cambridge.

Carston, R., 2002. Thoughts and Utterances: The Pragmatics of Explicit Communication. Blackwell, Oxford.

Chevallier, C., Noveck, I., Happé, F., Wilson, D., 2011. What's in a voice? Prosody as a test case for the Theory of Mind account of autism. Neuropsychologia 49, $507-17$.

Clark, B., 1993. A relevance-theoretic analysis of pseudo-imperatives. Linguistics and Philosophy 16, 79-121.

Clark, B., 2009. Salient inferences: Pragmatics and 'The Inheritors'. Language and Literature 18, 173-212. 
Clark, B., 2012. Beginning with 'One more thing': Pragmatics and editorial intervention in the work of Raymond Carver. Journal of Literary Semantics 41, 155-173.

Clark, B., 2013. Relevance Theory. Cambridge University Press, Cambridge.

Escandell-Vidal, V., Leonetti, M., Ahern, A. (Eds.), 2011. Procedural Meaning: Problems and Perspectives. Brill, Leiden.

Gutt, E.-A., 1991. Translation and Relevance: Cognition and Context. Blackwell, Oxford. (2nd edition, St Jerome Press, 2000)

Hall, A., 2007. Do discourse connectives encode concepts or procedures? Lingua $117,149-174$.

Ifantidou, E., 2001. Evidentials and Relevance. John Benjamins, Amsterdam. Iten, C., 2005. Linguistic Meaning, Truth Conditions and Relevance: The Case of Concessives. Palgrave, Basingstoke.

Jodlowiec, M., 2015. The Challenges of Explicit and Implicit Communication: $A$ Relevance-Theoretic Approach. Peter Lang, Frankfurt.

Matsui, T., 2000. Bridging and Relevance. John Benjamins, Amsterdam.

Matsui, T., 2002. Semantics and pragmatics of a Japanese discourse marker dakara ('so/in other words'): A unitary account. Journal of Pragmatics 34, 867-891.

Noh, E.-J., 2000. Metarepresentation: A Relevance-Theoretic Approach. John Benjamins, Amsterdam.

Papafragou, A., 2000. Modality: Issues at the Semantics-Pragmatics Interface. John Benjamins, Amsterdam. 
Powell, G., 2010. Language, Thought and Reference. Palgrave Macmillan, Basingstoke.

Sperber, D., Wilson, D. 1986. Relevance: Communication and Cognition. Blackwell, Oxford. (2 ${ }^{\text {nd }}$ edition 1995.)

Sasamoto, R., 2008. Japanese discourse connectives dakara and sorede: A reassessment of procedural meaning. Journal of Pragmatics 40, 127-154.

Unger, C., 2006. Genre, Relevance and Global Coherence: The Pragmatics of Discourse Type. Palgrave, Basingstoke.

Unger, C., 2012. Procedural semantics, metarepresentation, and some particles in Behdini Kurdish. Lingua 122, 1613-163.

Walaszewska, E., 2015. Relevance-Theoretic Lexical Pragmatics: Theory and Applications. Cambridge Scholars Press, Newcastle.

Wharton, T., 2003. Natural pragmatics and natural codes. Mind and Language 18, 447-477.

Wharton, T., 2009. Pragmatics and Non-Verbal Communication. Cambridge University Press, Cambridge.

Wilson, D., Sperber, D., 1988. Mood and the analysis of non-declarative sentences. In: Dancy, J., Moravscik, J., Taylor, C.C.W. (Eds.), Human Agency: Language, Duty and Value. Stanford University Press, Stanford, CA., pp. 77-101. (Reprinted in Wilson and Sperber, 2012, pp. 210-229.)

Wilson, D., Sperber, D., 1993. Linguistic form and relevance. Lingua 90, 1-25. (Reprinted in Wilson and Sperber, 2012, pp. 149-168.) 
Wilson, D., Sperber, D., 2012. Meaning and Relevance. Cambridge University Press, Cambridge.

Wilson, D., Wharton, T., 2006. Relevance and prosody. Journal of Pragmatics 38, 1559-1579. 